\title{
The Implementation and Results of the Academic Administration System in the Center for Education Quality Development Network under the Jurisdiction of the Office of the Basic Education Commission of Thailand
}

\author{
Phumiphat Ruanglae ${ }^{1}$, Chaiyuth Sirisuthi ${ }^{1} \&$ Visoot Weangsamoot ${ }^{2}$ \\ ${ }^{1}$ Faculty of Education, Mahasarakham University, Thailand \\ ${ }^{2}$ Faculty of Education, Chaiyaphum Rajabhat University, Thailand \\ Correspondence: Phumiphat Ruanglae, Faculty of Education, Mahasarakham University, Thailand. Tel: \\ 669-8564-5661.E-mail: phumiphat_r@hotmail.com
}

Received: June 22, 2016

doi:10.5539/ies.v10n3p199
Accepted: October 8, $2016 \quad$ Online Published: February 27, 2017

URL: https://doi.org/10.5539/ies.v10n3p199

\begin{abstract}
This purpose of this study was twofold. The researcher aimed to investigate the implementation results of the academic administration system in the Center for Education Quality Development Network under the jurisdiction of the Office of the Basic Education Commission of Thailand and to design the Actions Research which can be effectively utilized in academic administration. The system involved 5 steps including: 1) investigating the current situation, problems and development needs; 2) creating development guidelines; 3) identifying success indicators; 4) identifying development procedures; and 5) reflecting performance. When the system had been implemented in the $6^{\text {th }}$ Center for Education Quality Development Network with 16 schools in Nahaew district, it was found that the result of key success indicator assessment had the overall average at the moderate level. When each aspect being considered individually, it was found that the part with respect to students had most of the success indicators followed by the part pertaining to the internal quality assurance. The part with fewest success indicators was the participatory administration. Regarding the assessment of user's satisfaction after the system implementation, it was rated, as a whole, at the high level.
\end{abstract}

Keywords: network, educational quality, administration system

\section{Introduction}

\subsection{Introduce the Problem}

The Ministry of Education has set out with the aim to decentralize and let all parties concerned take part in the provision of education. This is in pursuant to the National Education Act (NEA) of 1999, amended in 2002, which stated the following requirements. A structural arrangement shall be made and the process of educational management shall be autonomous in policy but still diverse in actual practices. The ministry shall decentralize administrative powers, responsibilities, budget and personnel to all primary and secondary educational service area offices and schools and to all school committees as well. Decentralization will ensure the liquidity and freedom in administration based on the school based management (SBM) principle. This will help strengthen and lay the basis for all schools enabling them to provide students with a quality education, meet expected standards and to be developed continuously (The Office of the Basic Education Commission, 2004). To enable all educational service area offices and schools to administrate and provide education effectively and efficiently and to accommodate decentralization, The Office of the Basic Education Commission decided to set the network of educational institutions, also known as Center for Education Quality Development Network, in every educational service area office by virtue of section 37 of the Administrative Organization of the Ministry of Education Act of (2003) and the Ministerial Regulation on Criteria in Dividing Administrative Work in Primary Educational Service Area Offices 2010 (PESAO)'. The official announcement entitled 'The Establishment of the Center for Education Quality Development Network' was launched by PESAO then followed by the creation of regulations for the Center for Education Quality Development Network under the approval of the Committee of Educational Service Areas. This was operated as the process in order to stipulate the PESAO's regulations on the 
Center for Education Quality Development Network. Regarding the location of the center, it should be situated in the central partin order to provide convenience for all schools in the same area to commute and the schools joining the center should be located in the same district or the same local administrative organization. Each center consists of approximately 8-15 schools. The number can be higher but will not exceed 20, depending on the context and condition of each educational service area. However, the decision to increase the number of schools in one center must be under the approval of the Committee of Educational Service Area (Ruanglae, 2015).

\subsection{Explore Importance of the Problem}

The center was established with the following aims: 1) to promote the educational network system to be a pivotal mechanism in implementing policies based on the educational quality improvement plan; 2) to foster collaboration in preventing and addressing the problems in educational quality improvement and to increase the students' learning achievement; 3) to promote academic cooperation among schools in the same center and to share both human and physical resources for the students' utmost benefits; and 4) to increase schools' potentials and create readiness for decentralization. (Ministry of Education, 2008)

\subsection{Describe Relevant Scholarship}

The Center for Education Quality Development Network, however, failed to achieve its goals, especially the mission on educational quality improvement which is considered the main objective of the center. Such failure was due to many factors including a lack of budget to support the implementation, a lack of media and technology, a lack of planning participation from all parties concerned in the process of setting quality improvement plans and academic quality improvement plans which should be have been done collaboratively. The research conducted in 2005 by the Center for Education Quality Development Network in Monjong of Omkoy district revealed that most of the schools are located away from the city center. This caused the schools to be underprivileged with low potentials to be further developed. Furthermore, other factors included the lack of budget for schools in the rural area. The teachers in the studied area had to work hard with low moral support. This was due to the insufficiency of innovation, textbooks, laboratories and rooms for studying and activities, which consecutively induced negative impacts on the quality of instruction. Another study conducted in 2005 by the Center for Academic Improvement Network demonstrated that a substantial number of schools were heavily confronted with the problems pertaining to academic administration -be it the curriculum management, learning evaluation, research and development, project management, and academic work assessment (Ministry of Education, 2008).

\subsection{State Hypotheses and Their Correspondence to Research Design}

According to the educational improvement network, it was found that between academic years 2011 and 2013 the students' learning achievement, which is considered a significant indicator of educational success, was at the unsatisfactory level and some schools had never been successful when joining the academic skill competition. The result of the Ordinary National Education Test (O-Net) was relatively lower than the average score of sixth and ninth graders throughout the country. The students had poor performance-with score less than fifty percent, in several important subjects namely mathematics, science, social studies, Thai, and English. In particular, the students' average scores in three subjects - mathematics, science and English, were less than forty percent. The result of external quality assessment by the Office for National Education Standards and Quality Assessment in the second round revealed that out of 30,284 schools, there were 24,901 schools (82.22\%) under jurisdiction of the Office of the Basic Education Commission accredited and 5,383 schools (17.78\%) failed to meet the accreditation standards.

Therefore, the researcher, as the administrator of Loei Provincial Education Service Area Office, has explored the theoretical concepts of the participatory administration and the results-based management, the Deming Cycle then synthesized them into the concept which is applicable for developing the academic administration system of the Center for Education Quality Development Network under jurisdiction of the Office of the Basic Education Commission. There are 5 steps to take, including 1): 1) investigating the current situation, problems and development needs; 2) creating development guidelines; 3) identifying success indicators; 4) identifying development procedures; and 5) reflecting performance. The model was intended to improve the academic administration system of the Center for Education Quality Development Network under jurisdiction of the Office of the Basic Education Commission. The researcher envisages that there is a need to develop and strengthen the system in order that it can lead to sustainable efficiency. The system can serve as a mechanism to mobilize the education quality development, to enhance the achievement and to be used as a guideline for further improvement of educational quality. 


\section{Purposes}

1) To design the academic administration system of the Center for Education Quality Development Network under jurisdiction of the Office of the Basic Education Commission in Thailand.

2) To investigate the implementation results of the academic administration system of the Center for Education Quality Development Network under jurisdiction of the Office of the Basic Education Commission in Thailand.

\section{Methodology}

This research was conducted to develop the academic administration system with three steps as follows.

Phase 1. System Investigation and Analysis

In this stage, the researcher synthesized the system development procedures by adjusting certain details in the existing system to make it more applicable and by applying conceptual models initiated by several educational scholars and academics, namely Banghart (1969), Smith (1978), Biggs and others (1980), Edwards (1985), Kendal and Kendall (1988), Debenham (1989), Koowirat (1996), Harnkla (2002), Roophaen (2003), Butcharoen (2004).

\section{Phase 2. System Design}

The system was synthesized by utilizing several theoretical concepts and approaches including the Results-based Management (RBM), and the Deming Cycle, Participatory Administration \& Appreciation Influence Control (AIC) and by investigating current conditions and problems, needs, related literature and studies, and best practices. The synthesizing process required 5 steps as follows:: 1) investigating the current situation, problems and development needs; 2) creating development guidelines; 3) identifying success indicators; 4) identifying development procedures; and 5) reflecting performance.

Table 1. System synthesis

\begin{tabular}{|c|c|c|c|c|}
\hline $\begin{array}{l}\text { Deming } \\
\text { Cycle } \\
\text { (PDCA) } \\
\end{array}$ & Best Practice & $\begin{array}{l}\text { Results-based } \\
(\mathrm{RBM})\end{array}$ & $\begin{array}{l}\text { Appreciation Influence } \\
\text { Control (AIC) (Turid } \\
\text { Soto \&William) } \\
\end{array}$ & $\begin{array}{l}\text { Academic Administration System of } \\
\text { the Center for Education Quality } \\
\text { Development Network (SIGMA) }\end{array}$ \\
\hline & $\begin{array}{l}\text { 1. Surveying the } \\
\text { current academic } \\
\text { implementation of } \\
\text { the center }\end{array}$ & $\begin{array}{l}\text { 1. } \\
\text { - Setting the strategic plan } \\
\text {-Analyzing external and internal } \\
\text { environments } \\
\text {-Setting missions, objectives, } \\
\text { goals and working strategies by } \\
\text { taking into account significant } \\
\text { factors contributing to the } \\
\text { organizational success } \\
\text {-Setting work performance } \\
\text { indicators } \\
2 \text {. Surveying to acquire } \\
\text { information related to the current } \\
\text { condition }\end{array}$ & $\begin{array}{l}\text { A1 }=\text { Understanding } \\
\text { actual situation }\end{array}$ & $\begin{array}{l}\text { 1. S=Survey } \\
\text { Surveying current conditions, } \\
\text { problems and development needs } \\
\text { 1.1 Learners' quality } \\
1.2 \text { Teacher and personnel's' } \\
\text { development } \\
\text { 1.3 Participatory Administration } \\
\text { 1.4 Internal quality assurance system }\end{array}$ \\
\hline
\end{tabular}




\begin{tabular}{|c|c|c|c|c|}
\hline $\begin{array}{l}\mathrm{P}= \\
\text {-Planning } \\
\text {-Raising } \\
\text { awareness } \\
\text { Setting } \\
\text { guidelines } \\
\text { for } \\
\text { collaborati } \\
\text { ve } \\
\text { implement } \\
\text { ation }\end{array}$ & $\begin{array}{l}\text { 2.Developing } \\
\text { educational quality } \\
\text { by setting } \\
\text { educational } \\
\text { improvement plans } \\
\text { to develop students, } \\
\text { teachers and } \\
\text { educational } \\
\text { personnel } \\
\begin{array}{l}\text { 3. Setting the } \\
\text { academic } \\
\text { development } \\
\text { committee }\end{array} \\
\end{array}$ & $\begin{array}{l}\text { 3. Determining the detailed } \\
\text { description of work performance } \\
\text { indicators Making mutual } \\
\text { agreement in setting the } \\
\text { indicators both in qualitative and } \\
\text { quantitative perspectives }\end{array}$ & $\begin{array}{l}\mathrm{I}=\text { Creating development } \\
\text { guidelines is the process } \\
\text { involving creativity and } \\
\text { initiative in which each } \\
\text { team member has to: } \\
\text { I1:Seek out solutions to } \\
\text { achieve the intended } \\
\text { goal } \\
\text { I2 Prioritize and classify } \\
\text { activities }\end{array}$ & $\begin{array}{l}\text { 2. I=Influence } \\
\text { Creating development guidelines by } \\
\text { setting operational and strategic plans } \\
\text { and by considering factors contributing } \\
\text { to the success of the center } \\
2.1 \text { Students' learning performance } \\
2.2 \text { Teacher and personnel } \\
\text { development } \\
2.3 \\
\text { Participatory administration } \\
2.4 \\
\text { Internal quality assurance system }\end{array}$ \\
\hline $\begin{array}{l}\mathrm{D}=\text { Implem } \\
\text { enting the } \\
\text { plan }\end{array}$ & $\begin{array}{l}\text { 4.Sharing both } \\
\text { human and physical } \\
\text { resources }\end{array}$ & $\begin{array}{l}\text { 3. Determining the detailed } \\
\text { description of work performance } \\
\text { indicators Making mutual } \\
\text { agreement in setting the } \\
\text { indicators both in qualitative and } \\
\text { quantitative perspectives }\end{array}$ & $\begin{array}{l}\text { 3. Setting practical } \\
\text { guidelines by } \\
\text { determining the } \\
\text { implementing plan in } \\
\text { greater detail - that is to } \\
\text { indicate its principle, } \\
\text { rationale, and goals } \\
\text { 3.1 Seeking personnel to } \\
\text { assume the responsibility } \\
3.2 \text { Setting plans, } \\
\text { activities and projects }\end{array}$ & $\begin{array}{l}\text { 3. } \mathrm{G}=\text { Goal Establishing goals and } \\
\text { academic success indicators of the } \\
\text { network center } \\
\text { 3.1 Students' learning performance } \\
\text { 3.2 Teacher and personnel } \\
\text { development } \\
\text { 3.3 Participatory administration } \\
\text { 3.4 Internal quality assurance system }\end{array}$ \\
\hline & & $\begin{array}{l}3 . \\
\text { - Checking and evaluating the } \\
\text { operational result } \\
\text { - Reporting the operational result } \\
\text { of each indicator based the } \\
\text { stipulated conditions }\end{array}$ & & $\begin{array}{l}\text { 4. M= Management } \\
\text { Managing the plan in order to achieve } \\
\text { objectives and goals stipulated in each } \\
\text { indicator } \\
\text { 4.1 Students' learning performance } \\
4.2 \text { Teacher and personnel } \\
\text { development } \\
4.3 \text { Participatory administration } \\
4.4 \text { Internal quality assurance system }\end{array}$ \\
\hline $\begin{array}{l}\mathrm{C}= \\
\text { Checking } \\
\text { the } \\
\text { implement } \\
\text { ation } \\
\mathrm{A}= \\
\text { Reflecting } \\
\text { the } \\
\text { implement } \\
\text { ation }\end{array}$ & $\begin{array}{l}\text { 5. Researching and } \\
\text { developing } \\
\text { educational quality } \\
\text { Improving learning } \\
\text { resources and } \\
\text { educational } \\
\text { personnel } \\
6 . \text { Developing the } \\
\text { internal quality } \\
\text { assurance system } \\
7 . \quad \text { Reporting the } \\
\text { center's academic } \\
\text { implementation } \\
\text { results Personnel } \\
\text { 8. and } \\
\text { verification and } \\
\text { merit promotion }\end{array}$ & $\begin{array}{l}\text { 4. Rewarding the personnel after } \\
\text { evaluating the implementation } \\
\text { results as promised or } \\
\text { recommended } \\
\text { Establishing certain measures to } \\
\text { improve the operation and } \\
\text { achieve the intended goals. }\end{array}$ & & $\begin{array}{l}\text { 5. A=Act } \\
\text { Checking and reflecting the work } \\
\text { performance in four aspects: } \\
\text { 5.1 Students' learning performance } \\
\text { 5.2 Teacher and personnel } \\
\text { development } \\
\text { 5.3 Participatory administration } \\
\text { 5.4 Internal quality assurance system }\end{array}$ \\
\hline
\end{tabular}

Phase 3. System Implementation and Verification

This academic administration system was implemented with 90 school administrators, teachers and educational personnel in the Center for Education Quality Development Network of Loei Provincial Education Service Area Office 3 under the Jurisdiction of the Office of the Basic Education Commission. Simple random sampling was 
used. To collect data, the researcher employed the academic administration system and the questionnaire with which its validity was analyzed using the Index of Item-Objective Congruence (IOC) .60 mean and .87 reliability The questionnaire was composed of 21 items pertaining to students, 19 items related with teachers and personnel, 16 items involving participatory administration and 11 items in respect of the internal quality assurance. The user satisfaction survey was also utilized in this process.

Table 2. Implementation and tools

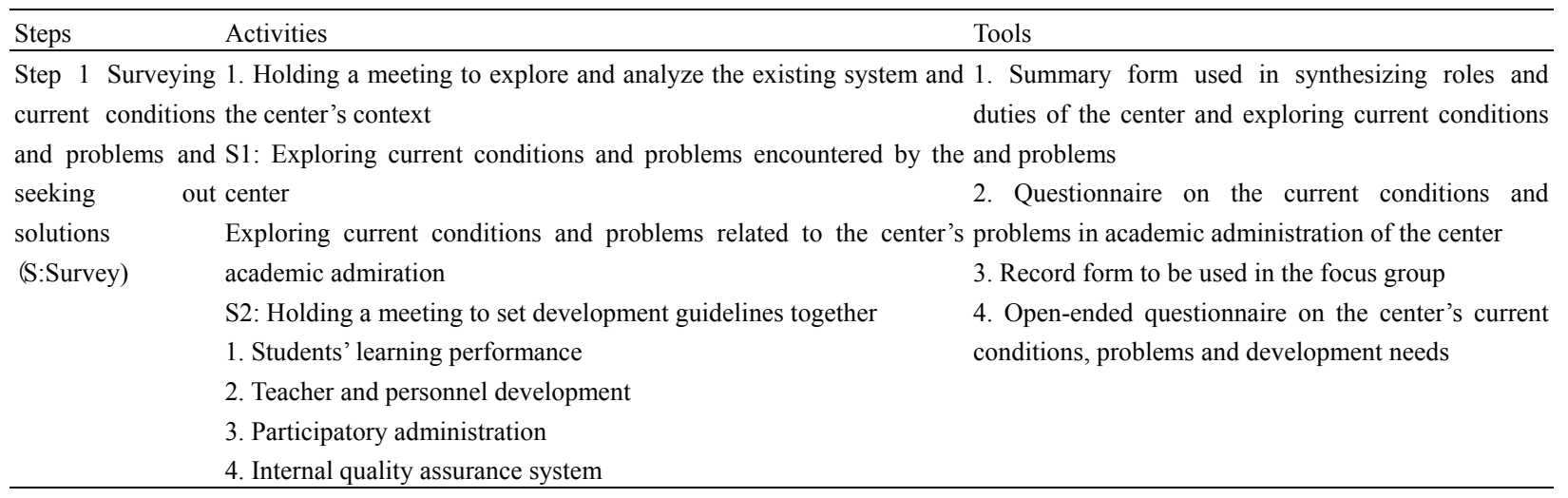

Step 2 Creating Creating development guidelines by planning the implementation in 4 Record form to be used during the educational development aspects: 1) Students' learning performance; 2) Teacher and personnel excursion to explore the best practice

guidelines by development; 3) Participatory administration; and 4) Internal quality Draft of the academic administration system of the planning (I: assurance system center for education quality development network Influence) I1: identifying the activities and projects to address the problems and which has been approved by the expert develop the center A user's guide of the system draft approved by the I2: Prioritizing the activities and projects expert

Step 3 3. Setting goals and key success indicators in 4 aspects including 1) Assessment form of the center's key success (G:Goal) Students' learning performance; 2) Teacher and personnel indicators in 4 aspects development; 3) Participatory administration; and 4) Internal quality assurance system

Step 4 (M: 4. Identifying development methods in 4 aspects: 1) Students' 1. Observation form to be used while the system Management) learning performance; 2) Teacher and personnel development; 3) being implemented

Participatory administration; and 4) Internal quality assurance system 2. Record form used in informal knowledge exchange M1: Assigning personnel to assume the responsibility in activities 3. Record form to reflect the implementation results and projects 4. Assessment form of key success indicators after the M2: Setting details and operating activities and projects system implementation

Step 5 (A: Act) 5. Reflecting work performance by checking and reflecting the 1. User satisfaction questionnaire implementation in 4 aspects: 1) Students' learning performance; 2) Teacher and personnel development; 3) Participatory administration; and 4) Internal quality assurance system

A1: Assessment

A2: Recommendation

\section{Results}

The development the academic administration system resulted in a five-step conceptual model. Such steps included 4.1 Surveying current conditions, problems and development needs (Survey: S); 2) Creating development guidelines by planning the implementation (Influence: I); 3) Setting goals and key success indicators (Goal: G); 4) Identifying development methods (Management: $\mathrm{M}$ ); and 5) Reflecting work performance (Act: A) as illustrated in Figure 1. 


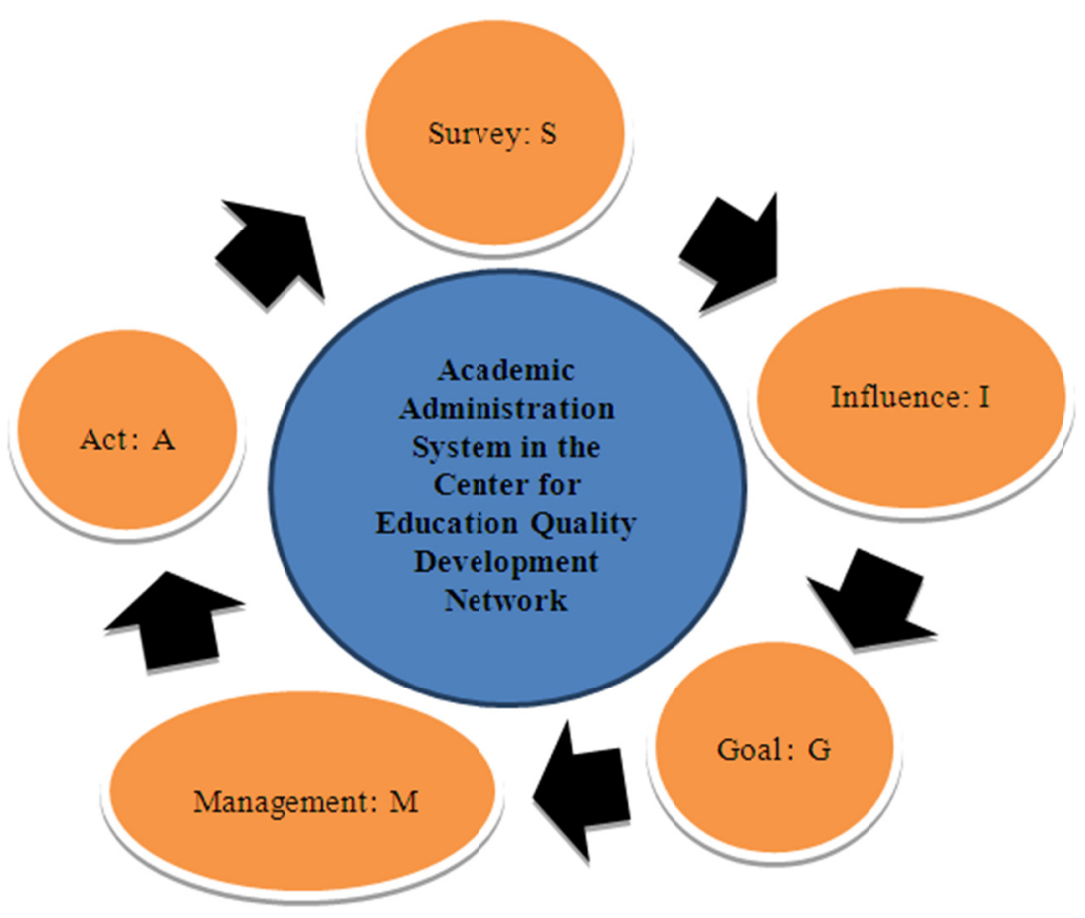

Figure 1. Academic administration system in the center for education quality development network

Results of the implementation of the Academic Administration System in the Center for Education Quality Development Network under the Jurisdiction of the Office of the Basic Education Commission of Thailand

Regarding the key success indicator assessment, it was found that the success in student development was at the moderate level as shown in Table 3.

Table 3. Results of key success indicator assessment

\begin{tabular}{lccc}
\hline Key Success Indicator & $\overline{\mathrm{X}}$ & S.D. & Result \\
\hline 1. Students & 2.57 & 0.93 & moderate \\
2. Teachers and educational personnel & 2.51 & 0.83 & moderate \\
3. Participatory administration & 2.51 & 1.00 & moderate \\
4. Internal quality assurance system & 2.45 & 0.28 & little \\
Overall & 2.51 & 0.89 & moderate \\
\hline
\end{tabular}

The user satisfaction after the system implementation was rated as a whole at the high level $(\bar{x}=4.09)$. When considered individually, each item was also rated at the high level.

\section{Discussion}

The five-step conceptual model corresponds with the findings previously investigated by the following researchers. First, Thepkraiwan (2011) developed a cooperation model to improve educational management in small sized schools. His model comprised 6 steps including: 1) being aware of needs to create the network; 2) coordinating with the network; 3) making mutual agreements; 4) administrating the network; 5) enhancing relationship; and 6) sustaining relationship. The components of the cooperation network for educational quality included 1) significant activities to pave the way to reach the network's goals; 2) scope and missions of school administration; 3) techniques or methods to develop network members; 4) empowerment process; 5) good characteristics of the network leader; and 6) network's operation and feedback. Moreover, the findings of this research also correspond with Boonsong's (2001) study. Boonsong investigated the cooperation model appropriate for schools and families to manage education. This cooperation model requires equal participation from the two sides. Schools and families have equal rights in the process education management and administration. The model stresses the importance of decision making, cooperation and shared advantages with 
the aim to develop education and yield the utmost benefit to the students. Educational management operated by families has a distinctive feature when compared with the one operated by schools. Both have their own uniqueness. When blended together, desired outcomes will benefit the students, who are regarded as the most important goal of the educational reform. The findings also correlate with Smith's research (1991). Smith researched into the characteristics of efficient schools in Georgia. His findings revealed the significant components contributing to school efficiency, namely regular assessment and evaluation, enhancement of academic environment, and strong leadership. However, it was found that high expectation and collaborative work were negatively related to school efficiency. This corresponds with Norwich and Evans's (2007) study entitled 'Cluster: Inter-school collaboration in meeting special educational needs in ordinary schools'. Their findings reported several methods to enable schools to meet special educational needs collaboratively. They illustrated several forms of inter-school collaboration and certain factors which correlate with the implementation. The findings associated with these factors were elaborated both negatively and positively. Norwich and Evans's findings depicted significant principles and contributed to special educational assistance. It was assumed that their findings would benefit those interested in developing and sustaining special educational assistance. Norwich and Evans believed that their findings were essential in the sense that they could provide special educational assistance. This would certainly raise awareness in restructuring the educational service in collaborative systems. The clusters helped foster a good relationship among schools and involved the brainstorming process which is important in the present-day situation. Their crucial point was the establishment of clusters was statically significant and involved the components appropriate for assisting the students via means of special education needs. However, we should not be aware of its positive potentials only. Certain risks and limitations should be also taken into account. Besides, we should be aware that there exist several others methods to support the students. When schools mutually agree that they will establish the cluster, it reflects the cluster's flexibility.

\section{Results of the system implementation are illustrated as follows}

After assessing the key success indicators of the system, it was found that the success with respect to the student development in Nahaew district was at the moderate level, teacher and personnel development at the moderate level, participatory administration at the low level and internal quality assurance system at the low level. These findings correspond with Wisesrinthong's study in 2012. Wisesrinthong undertook research entitled 'The development of classroom management system forextended educational opportunity schools ' and found that teachers knew and understood the classroom management better after joining the workshop with the significance level 0.1. Overall, the students' desired behavior and their self-discipline and passion for learning were rated at the high level. Their determination was rated at the moderate level. Furthermore, Puedsing (2010) carried out research on the development of the effectiveness oriented administrative system in Suksa Songkhro School and reported three principal components. The first important part was the input which involved the school administrator's leadership, policy implementation and actual practices, organizational characteristics, environments, teachers and educational personnel, and students. The second part involved the process which covered the processes of analysis, planning, operation, assessment and conclusion. The final component is the product which included the user's guide to the effectiveness oriented administrative system which would consecutively induce positive impacts on the student—enabling them to be intelligent, virtuous and happy. It was found that this administrative system could be translated into the actual practice and successful.

The findings revealed the results of user satisfaction assessment being rated, as a whole, at the high level ( $\bar{X}=$ 4.09). When considered individually, every item was rated at the high level. There was a correlation between these findings and Wisetrinthong's (2012) study. Wisetrinthong carried out research entitled 'The development of classroom management system for extended educational opportunity schools' and found that the school administrators an teachers' satisfaction about the classroom management system was rated at the highest level and the students' satisfaction about their teachers' classroom management techniques was at the high level. Based on the teachers' opinion after implementing the system, the system suitability was at the high level.

\section{References}

Banghart, F. W. (1969). Education Systems Analysis. New York: Collier McMillan.

Biggs, C. L., Birks, E. G., \& Atkins, W. (1980). Managing the Systems Development Process. Englewood Cliffs, NJ: Prentice-Hall.

Boonsong, C. (2001). The investigation of educational management and administration of local administrative organizations in Japan: Research report. Bangkok. Office of the National Education Commission, Prime Minister's Office. 
Butcharoen, J. (2004). Developing the evaluation and assessment utilized in health and physical education contents in secondary schools. Bangkok: Chulalongkorn University.

Edwards, P. (1985). System analysis design and development: with structure Concepts. New York: Holt Rinehart and Winston.

Harnkla, C. (2002). The development of the internal quality assurance follow-up system in Rajabhat Institutes (Doctoral dissertation, Bangkok: Chulalongkorn University).

Koowirat, W. (1996). The Development of the Teacher Performance Appraisal System in the Catholic Schools under the Supervision of Bangkok Archdiocese (Doctoral dissertation, Bangkok: Chulalongkorn University).

Ministry of Education. (2008). Practical Guidelines for Participation-based Educational Management. Bangkok: The Agricultural Cooperative Federation of Thailand, Limited.

Norwich and Evans. (2007).Cluster: Inter-school collaboration in meeting special educational needs in ordinary schools. Retrieved from http://www.ebscohot.com/ehost/detail?vid=11\&hid=113\&sid=3b84db3b-45f9

Office for National Education Standards and Quality Assessment. (2011). Seminar and brainstorming: From the assessment results to documentation development presented to the meeting on Thai educational quality improvement. Surat Thani

Phumiphat Ruanglae. (2015). Development of Center Academic Network for Development of Educational Quality of Basic Educational Commission Office (Doctoral dissertation, Mahasarakham: Mahasarakham University).

Puedsing, A. (2010). The development of administration system aimed at effective welfare schools (Doctoral dissertation, Mahasarakham: Mahasarakham University).

Roophaen, P. (2003). The development of the work performance assessment system in Basic education Commission (Doctoral dissertation, Bangkok: Chulalongkorn University).

Smith, A. (1991). Management System: Analyses and Application. New York: The Dryden Press. The center for academic development network. The center for educational quality development network, Monjong, 2005.

Smith, W. A. (1978). System Concept, Total. Encyclopedia of Professional Management.

The Office of the Basic Education Commission. (2004). The user's guide to basic education school administration as juristic persons. Bangkok: Kurusapa Printing

Thepkraiwan, P. (2011). The development of the participatory network for educational management in small primary schools (Doctoral dissertation, Khon Kaen: Khon Kaen University).

Wisetrinthong, K. (2012). System classesroom management for expanded educational opportunities school (Doctoral dissertation, Mahasarakham: Mahasarakham University).

\section{Copyrights}

Copyright for this article is retained by the author(s), with first publication rights granted to the journal.

This is an open-access article distributed under the terms and conditions of the Creative Commons Attribution license (http://creativecommons.org/licenses/by/4.0/). 